\title{
High-Lights of Epilepsy 2015
}

\author{
Raili Riikonen* \\ Children`s Hospital and Science Service Center, University of Kuopio, Finland
}

\begin{abstract}
There have been many recent advances in epilepsy. Here only a few advances have been selected from large numbers of publications during 2013-2015. Many important publications (inflammation in neurological diseases, optokinetic therapies, functional MRI etc.) that would have been worth of presentation were not included. The following four topics were chosen: enlarged indication of ketogenic diet, restriction of use of valproate for women, targeted gene therapy for epilepsy, and advances of animal studies. The selection of these topics were based on the personal interest of the writer.
\end{abstract}

\section{Commentary}

In this short review the following high-lights of epilepsy 2015 were selected and presented by me at EPNS Congress in $11^{\text {th }}$ European Pediatric Congress, May 302015 in Vienna.

1. Ketogenic diet

2. Valproate and pregnancy

3. New gene-targeted therapies

4. Animal models

\section{High-lights}

The indication of ketogenic diet (KD) have been broadened $[1,2]$ : Its indications have been in refractory infantile spasms [3], LennoxGastaut syndrome [4]. Now it has been recommended as therapy in Dravet syndrome [5], Rett syndrome [6] and Glut-1 deficiency $[7,8]$. Hallbook et al. 2015 [9] has published a retrospective study in 290 children from Scandinavian countries with KD which was effective, even in patients with severe therapy-resistant epilepsy. Use of dietary therapy for status epilepticus is a new indication of $\mathrm{KD}$ [10]. A significant improvement in seizure-frequency was seen in atonic seizures at three months and secondary generalized seizures at three months and six months of ketogenic diet. It was effective and well-tolerated treatment option for patients with refractory status epilepticus [11,12]. In superrefractory status epilepticus it has been used intravenously when two treatments have been ineffective. [11,13].

Valproic acid (VPA) and pregnancy: There has been recent restrictions of VPA use: "VPA should not be used to treat epilepsy in women who are pregnant or who can become pregnant unless other treatments are ineffective or not tolerated. Women for whom valproate is the only treatment is the only option after trying other treatments, should use effective contraception and treatment should be started and supervised by a doctor experienced in treating these conditions." This statement was made by European Pharmacovigilance Risk Assessment Committee (PRAC) October 2014 [14].

However, later (2015) there came less restrictive recommendations by ILEA: Valproate in the treatment of epilepsy in women and girls [15] including the following statements:
- "Not as a first-line treatment for focal epilepsy

- May be offered as 1 . line treatment for epilepsy syndromes where it ismost effective treatment or

- where pregnancy isunlikely

- Risk/benefit assessments should bemade."

New gene-targetedtherapies: Many forms of epilepsy are likely to have a genetic background. There has now been an explosion of genetics in epilepsy. Earlier, it has been questioned if genetic information helps us to treat patients. "Pro--genetic information in humans helps us to treat patients. Con--genetic information does not help at all" [16].

The importance of improved understanding of the genetics of epilepsies is now confirmed by the positive outcomes, in terms of treatment selection and counselling after receiving a genetic diagnosis [17]. "Epilepsy genetics revolutionizes clinical practice" [18].

In fact, there are already few new gene-targeted therapies. An example is given here.

KCNT1 and quinidine: Migrating partial seizures of infancy is an early onset epileptic encephalopathy syndrome that is typically resistant to treatment. The most common cause is a gain of function in the potassium channel KCNT1. De novo gain-of-function KCNT1 channel mutations cause malignant migrating partial epilepsy [19]. Missense mutations in the sodium-gated potassium channel gene KCNT1 cause severe autosomal dominant nocturnal frontal lobe (ADNFLE) epilepsy [20]. The antiarrhythmic drug quinidine is a partial antagonist of KCNT1 and hence may be a candidate drug for treatment of this condition. It may rescues mutant channels. Treatment with quinidine reduced markedly seizure frequency and improved psychomotor development [21,22].

Correspondence to: Riikonen R, MD, PhD, Professor of Child Neurology, Children`s Hospital and Science Service Center, University of Kuopio, Finland, Tel: +358 505174696, Fax: +358 19668418; E-mail: raili.riikonen@kolumbus.fi

Key words: ketogenic diet, valproate, gene-targeted therapy, animal studies

Received: October 29, 2015; Accepted: November 24, 2015; Published: November 28, 2015 
Mammalian Target of Rapamycin(m-TOR): The m-Tor pathway is the master regulator of cell growth and homeostasis. The target of rapamycin is a serine-threonine kinase. M-Tor activation is repressed at the lysosomal membrane in response to the metabolic stress of amino acidstarvation.

Tuberous sclerosis(TS): TS has been attributed to mutations in the TSC1 and TSC2 genes. These genes, known as tumor suppressors, are responsible for the inhibition of $\mathrm{m}$-Torpathways. Mutations of these genes cause hyperactivation of the $\mathrm{m}$-Tor system and result in excessive cell growth and hamartomatous tumors in multiple organs [23].

Rapamycin prevents epilepsy in a mouse model of tuberous sclerosis complex [24]. In humans, rapamycin treatment of refractory epilepsy in tuberous sclerosis complex has been recently been shown effective [25,26].

DEPDC5 (DEP domain-containing protein 5) mutation: DEPDC5 gene mutations cause focal non-lesional focal epilepsy and focal dysplasia [27]. It is the first gene for non-lesional focal epilepsy (7/8 families with familial focal epilepsy with variable foci (FFEVF) had DEPDC5 mutations). Penetrance is on average 66\%.

DEPDC5 gene mutations for focal variable familial epilepsy with variable foci and in more $10 \%$ (10/82 patients) of small families with non-lesional focal epilepsy [28]. This high frequency establishes DEPDC5 mutations as a common cause of familialfocal epilepsies. DEPDC5 has also recently been reported in a broad spectrum of inherited epilepsies (ADNFLE, familial temporal lobe epilepsy (FTLE) and FFEVF [29]. No clinical evidence of multisystem involvement was found in individuals with DEPDC5 mutations. Because DEPDC5 acts as a repressor of $\mathrm{m}$-TOR activity.DEPDC5 mutations are predicted to result in excessive $\mathrm{m}$-TOR signaling. Consistent with this, individuals with DEPDC5 mutations share similar features with patients with other m-TORopathies such as tuberous sclerosis with dysplastic lesions, focal epilepsy, autism spectrum disorders, and intellectual disability. Mammalian target of rapamycin pathway mutations cause hemimegalencephaloly and focal cortical dysplasia [30].

Animal models: Animal models of epilepsy give information on candidate new therapies, insights on etiology-based pathogenesis and epileptogenesis. Several models have tested the impact of subclinical epileptiform discharges on brain function. There are 5 models for infantile spasms (CRH/stress: betamethasone, NMDA model, TTX, multiple-hit models, ARX knockout, Down syndrome. There are models for Dravet syndrome and Tsc2+/- mouse model of tuberous sclerosis [31].

\section{Conclusions}

The high-lights presented here are diverse items that have been very recently published. Some of them are of practical interest. Few gene targeted therapies are already available. Candidate new therapies based on animal experiments are promises for the future.

\section{References}

1. Kossoff E, Cervenka M, Henry B, Haney C, Turner Z (2013) A decade of modified Atkins diet (2003-2013): Results, insights, and future directions. Epilepsy Behav 29: 437-442. [Crossref]

2. Stafström C (2013) Dietary therapies for epilepsy and other neurological disorders: Highlights of the 3 International Symposium Epilepsy Currents 13:103-106. [Crossref]

3. Kossoff E, Pyzik P, McGrogan J, MCGrogan J, Vining E, et al. (2003) Efficacy of the ketogenic diet for infantile spasms. Pediatrics 109:780-783. [Crossref]
4. Lemmon M, Terao N, Ng YT, Reisig W, Rubenstein J (2012) Efficacy of ketogenic diet in Lennox-Gastaut syndrome: A retrospective review of one institution's experience and summary of the literature. Dev Med Child Neurol 54: 464-468. [Crossref]

5. Dressler A, Trimmel-Schwahofer P, Reithofer E, Gröppel G, Muhlebner A, et al. (2015) Efficacy and tolerability of the ketogenic diet in Dravet syndrome-Comparison with various standard antiepileptic drug regimen. Epilepsy Res 109:81-89. [Crossref]

6. Dolce A, Ben -Zeev B, Naidu S,Kossof E (2013) Rett syndrome and epilepsy: An update for Child Neurologists. Pediatric Neurology 48: 337-345. [Crossref]

7. Veggiotti P, Teutonico F, Alfei E, Nardocci N, Zorzi G, et al. (2010) Glucose transporter type 1 deficiency: ketogenic diet in three patients with atypicalphenotype. Brain Dev 32: 404-408. [Crossref]

8. Bertoli S, Trentani C, Ferraris C, De Giorgis V, Veggiotti P, et al. (2014) Long- term effects of a ketogenic diet oon body composition and bone mineralization in GLUT-1 deficiency syndrome: a case series. Nutrition 50: 726-728. [Crossref]

9. Hallbook T, Sjölander A, Amark P, Miranda M, Bjurulf B, et al. (2015) Effectiveness of the ketogenic diet used to treat resistant childhood epilepsy in Scandinavia. Eur J Pediatr Neurol 19: 29-36. [Crossref]

10. Kossoff E, Nabbout R (2013) Use of dietary therapy for status epilepticus. J Child Neurol 28: 1049-1051. [Crossref]

11. Caraballo R, Flesler S, Armeno M, Fortini S, Agustinho A (2014) Ketogenic diet in pediatric patients with refractory focal status epilepticus. Epilepsy Res 108: 1912-1916. [Crossref]

12. O`Connor S, Ream M, Richardson C, Mikati M, Trescher W, et al. (2014) The ketogenic diet for the treatment of pediatric status epilepticus. Pediatr Neurol 50: 101103. [Crossref]

13. Lin J, Lin K, Chan O, Hsia S, Wang H (2015) Intravenous ketogenic therapy for treatment of the acute stage of super- frectary status epilepticus in a pediatric patient. Pediatr Neurol 52: 442-445. [Crossref]

14. http://www.ema.europa.eu/ema/index,jsp2014/10

15. Tomson T, Marson A, Boon P, Canevini M, Covanis A, et al. (2015) Valproate in the treatment of epilepsy in women and girls. Recommendations from the Joint Task Force of ILEA. Commision on European Affairs and European Academy of Neurology (EAN). Epilepsia 56: 1009-1019. [Crossref]

16. Delgato-Escueta A, Borgeois (2008) Debate: does genetic information in humans help us Treat patients. PRO - genetic information in humans helps ustreatpatients. CONgenetic information does not help at all. Epilepsia 9: 13-24. [Crossref]

17. Thomas R, Berkovic S (2014) The hidden genetics of epilepsy- a clinically importan new paradigm. Nat Rev Neurol 10: 283-292.

18. Scheffer I (2014) Epilepsy genetics revolutionizes clinical practice. Neuropediatrics 45: 70-74. [Crossref]

19. Barcia G, Fleming M, Deligniere A, Gazula V, Brown M, et al. (2012) De novo gainof-function KCNT1 channel mutations cause malignant migrating partial seizures of infancy. Nat Genet 44: 1255-1259. [Crossref]

20. Heron S, Smith K, Bahlo M, Nobilli L, Kahana E, et al. (2012) Missense mutations in the sodium-gated potassium channel gene KCNT1 cause severe autosomal dominant nocturnal frontal lobe epilepsy. Nature Genetics 44:1888-1890. [Crossref]

21. Bearden D, Strong A, Ehnot J, DiGiovine M, Dlugos D, et al. (2014) Targeted treatment of partial seizures of infancy with quinidine. Ann Neurol 76: 457-461. [Crossref]

22. Milligan C, Li M, Gazina E, Heron S, Nair U, et al. (2014) KCNT1 gain of function in 2 epilepsy phenotypes is reversed by quinidine. Ann Neurol 75: 581-590. [Crossref]

23. Crino P (2013) Evolving neurobiology of tuberous sclerosis complex. Acta Neuropathol 125: 444-443. [Crossref]

24. Zheng L, Xu L, Gutmann D, Wong M (2008)Rapamycin prevents epilepsy in a mouse mode of tuberous sclerosis complex. Ann Neurol 63: 444-453. [Crossref]

25. Krueger D (2013) Everolimus treatment of refractory epilepsy in tuberous sclerosis complex. Ann Neurol 74: 679-687. [Crossref]

26. Canpolat M, Per H, Gumus H, Yikilmaz A, Unal E, et al. (2014) Rapamycin has a beneficial effect on controlling epilepsy in children with tuberous sclerosis complex; results of 7 children from a cohort of 86. Childs Nerv Syst 30: 227-240. [Crossref]

27. Scheffer I, Heron S, Regan B, Mandelstam S, Cropton D, et al. (2014) Mutations in mammalian target of rapamycin regulator DEPDC5 cause focal epilepsy with brain malformations. Ann Neurol 75:782-787. [Crossref] 
28. Dibbens L, de Vries B, Donatello S, Heron S, Hodgson B, et al. (2013) Mutations in DEPDC5 cause familial focal epilepsy with variable foci. Nature Genetics 45: 546-551. [Crossref]

29. Baulac S (2014) Genetics advances in autosomal dominant focal epilepsies: focus on DEPDC5. Prog Brain Res 213: 123-139. [Crossref]
30. D'Gama A, GengY, Couto J, Martin B, Boyle E, et al. (2015) Mammalian target of rapamycin pathway mutations cause hemimegalencephaly and focal cortical dysplasia. Ann Neurol 77: 720-725. [Crossref]

31. Galanopoulou AS, Moshé SL (2015) Pathogenesis and new candidate treatments for infantile spasms and early life epileptic encephalopathies: A view from preclinical studies (2015). Neurobiol Dis 79: 135-149. [Crossref]

Copyright: $\mathbb{C} 2015$ Riikonen R. This is an open-access article distributed under the terms of the Creative Commons Attribution License, which permits unrestricted use, distribution, and reproduction in any medium, provided the original author and source are credited. 